Vol. 8(6), pp. 74-80, July 2016

DOI: $10.5897 /$ IJWREE2015.0568

Article Number: 279414159507

ISSN 2141-6613

Copyright (C) 2016

Author(s) retain the copyright of this article

http://www.academicjournals.org/IJWREE
International Journal of Water Resources and Environmental Engineering

\title{
Analysis of water quality of Selameko man-made reservoir using physico-chemical parameters for fishery, Debre Tabor, South Gondar (Ethiopia)
}

\author{
Tilahun Adugna $^{1 \star}$ and Ayale Wondie ${ }^{2}$ \\ ${ }^{1}$ Addis Ababa University Ethiopia. \\ ${ }^{2}$ Department of Biology, Faculty of Natural Science, Bahir Dar University Ethiopia.
}

Received 17 February, 2015; Accepted 7 October, 2015

\begin{abstract}
Water quality is connected with physical, chemical and biological (including bacteriological) characteristics and these characteristics are determined the healthy status of any aquatic ecosystem. To determine whether the water quality of Selameko reservoir is good for fishing, physico-chemical parameters measurements were made. Water quality parameters, such as temperature, water transparency, water depth, dissolved oxygen, $\mathrm{pH}$, total dissolved solids, phosphate, nitrate, and silicate were measured in-situ from two sites (littoral and open water zone) of the reservoir. Temperature of the water of the reservoir ranged from 18.7 to $24.2^{\circ} \mathrm{C}$, water depth (only for open zone) 10.5 to $13.04 \mathrm{~m}, \mathrm{pH}$ 7.01 to 8.01 , DO 5.0 to $6.15 \mathrm{mg} / \mathrm{l}$, transparency depth 32 to $97 \mathrm{~cm}$, TDSs 67.1 to $137.2 \mathrm{ppm}, \mathrm{NO}_{3}-\mathrm{N} 0.1$ to 2 $\mathrm{mg} / \mathrm{l}, \mathrm{PO}_{4}-\mathrm{P} 0.08$ to $0.83 \mathrm{mg} / \mathrm{l}$ and Silicate 0.09 to $22.5 \mathrm{mg} / \mathrm{l}$. ANOVA result of the physicochemical parameters showed presence of significance difference among seasons and between sites $(p<0.05)$. The study concluded that some of physicochemical parameters such as $\mathrm{NO}_{3}-\mathrm{N}$ and $\mathrm{PO}_{4}-\mathrm{P}$ were indicated the presence of reservoir water pollution and not good fishing activity. The reservoir water was eutrophic (productive) throughout the year. To avoid such pollution, basin and reservoir management are recommended.
\end{abstract}

Key words: Physco-chemical parameters, fish, temperature, aquatic.

\section{INTRODUCTION}

Ethiopia has many small, medium and large reservoir dam constructed for hydropower generation, irrigation and drinking water supply (FAO, 2010). Even though dam reservoirs are providing these values, they are unable to achieve their end goal due lack of good water quality. The most important challenges are accumulation of excess sediments (Abood et al., 2009; Lee et al., 2009; Cowie, 2002; White and Bettess, 1994), eutrophication
(Granit and Lindstrom, 2009; Henry et al., 2004; Little, 2004), toxicity (Holdren et al., 2001), as well as threatening factors, such as clearing of lands, application of agriculture fertilizers and pesticides for the surrounding farm land, rural and urban settlement, industrial development (Granit and Lindstrom, 2009; Mustapha,, 2008; Ostojic et al., 2005); high demographic density (Jansky et al., 2002), release of untreated wastewaters

*Corresponding author. E-mail: adugnawassie@gmail.com, tilahun46@yahoo.com. Tel: (251) 920518591. 
(Henry et al.,, 2004), land use pattern of watershed and sanitary situations of inhabitants (Bhattarai et al.,, 2008), etc. Most of the challenges are the problems of all reservoirs which are found throughout the world and unavoidable (Abood et al., 2009).

Generally, water quality is connected with physical, chemical and biological (including bacteriological) characteristics (Straskraba and and Tundisi, 1999; Nancy,, 2009) and these characteristics are determined the healthy status of any aquatic ecosystem (Venkatesharaju et al., 2010). Therefore, assessing the quality of water in any ecosystem provides significant information about the available resources for supporting life in that ecosystem. Once, the physicochemical characteristics of water bodies are affected then species composition, abundance, productivity and physiological conditions of aquatic organisms are badly affected (Granit and Lindstrom, 2009; Goldman and Horne,, 1983). Before the water quality is deteriorated, checking their current status of the reservoir water so crucial to give urgent resolution. Therefore, the present study was conducted to understand the physicochemical properties of Selameko man-made reservoir for fishing activity for one year from August 2009 to May 2010.

\section{METHODOLOGY}

\section{Description of the study area}

This study was conducted at Selameko manmade reservoir, Debre Tabor Town, Ethiopia. This man-made reservoir is found $2513 \mathrm{~m}$ above sea level (masl), specifically located at $38^{\circ} 05^{\prime} \mathrm{E}$ and $11^{\circ} 53^{\prime}$ 24" N (Figure 1). The reservoir was constructed in 2007 with a total of 11.6 ha of area and $20 \mathrm{~m}$ depth to irrigate nearly 63 ha. The catchments are extended from 2513 to 2726 masl with 879.25 ha of total areas. The reservoir water fluctuate was mainly depending on inflows: rain from the catchments and supply from Selameko river; and outflows connected with releasing for irrigation and dam crack, and due to direct evaporation of reservoir water. Because of the presence of these unbalance, the water depth was decreased by (from $13.04 \mathrm{~m}$ at August, first sampled month to $10.50 \mathrm{~m}$ at the first week of May, the last sampled month) $2.54 \mathrm{~m}$ in one year. Totally $6.96 \mathrm{~m}$ depth of the reservoir was filled by silts within three years.

\section{Climate and hydrology}

Based on the National Metrology Agency of Bahir Dar Branch Office, the study area mean annual temperature was $16.23^{\circ} \mathrm{C}$ (minimum $9.2^{\circ} \mathrm{C}$ and maximum $23.26^{\circ} \mathrm{C}$ ) (from 1997 to 2009), and its mean annual rainfall was $1371.2 \mathrm{~mm}$ (minimum $1096.7 \mathrm{~mm}$ and maximum $1645.7 \mathrm{~mm}$ ) (from 1999 to 2009). The climate of Selameko reservoir is characterized roughly by four seasons: (1) A main-rainy season (MRS) with heavy rains during July-September, (2) a post-rainy season (PORS) between October to November, (3) a dry season (DS) between December to April and (4) a pre-rainy season (PRS) from May to June (Tamiru, 2006; Ayalew et al., 2007).

Physicochemical samples were collected in one year, from August 2009 to May 2010 in the four seasons, that is, main rainy season /MRS/, post-rainy season /PORS/, dry season /DS/ and prerainy season /PRS/. The water samples were taken only from littoral
(SI) and open water zone (SII) two times from each for each parameter (Figure 1).

Water temperature and $\mathrm{pH}$, total dissolved oxygen (TDO), total dissolved substances (TDSs) and water transparency were determined in-situ. Water temperature and $\mathrm{pH}$ were measured with coupled $\mathrm{pH} / \mathrm{TDS} / \mathrm{CON}$ Meter (Model Tochpro II); TDO was determined by portable oxygen analyzer (JPB-607); total dissolved substances /TDSs/ was measured by cond/TDS meter (Model CE 470 Cond. Meter 01189); water transparency depth (WTD) was measured by standardized meter and transparency was measured by standardized Secchi disc (having white and black color with 25 $\mathrm{cm}$ in diameter). The physco-chemical parameters measurements were taken after the probes dipping down from the surface water to $50 \mathrm{~cm}$ down in the reservoir water. Major nutrients, nitrate $\left(\mathrm{NO}_{3}-\mathrm{N}\right)$, phosphate $\left(\mathrm{PO}_{4}-\mathrm{P}\right)$ and silicate $\left(\mathrm{SiO}_{2}\right)$ were measured in-situ immediately by using a portable water analyzer kit (Wagtech international, Palintest transmittance display photometer 5000 Palintest Ltd., and UK) (Palintest Ltd.,1989). The collected water samples from the two sites were first filtrate by Whatman GF/C, 0.6 to $0.7 \mu \mathrm{m}$ pore size membrane filter.

\section{Data analyses}

Analysis of variance (ANOVA) was used to test significant differences between those like spatial and temporal variations of physico-chemical $(p<0.05)$. Tukey (Honestly Significantly Differently Test) test was used to determine significance in mean catches and estimates. In general, data were calculated and organized using appropriate statistical software, such as the SPSS (2007) version 16 and SAS (2003).

\section{RESULTS}

\section{Physicochemical measurements (in seasons and sites)}

Temperature of the reservoir water ranged $18.7^{\circ} \mathrm{C}$ (PORS) to $24.2^{\circ} \mathrm{C}$ (DS) $\left(21.5 \pm 1.28^{\circ} \mathrm{C}, \mathrm{SI}\right)$ and $19.7^{\circ} \mathrm{C}$ (MRS) to $24.2^{\circ} \mathrm{C}$ (DS \& PRS) $\left(22.23 \pm 1.16^{\circ} \mathrm{C}\right.$, SII). The reservoir water depth of the open water was between 10.5 $\mathrm{m}$ (PRS) to $13.04 \mathrm{~m}$ (MRS) $(11.33 \pm 0.58 \mathrm{~m})$. The $\mathrm{pH}$ of the reservoir extended from 7.42 (DS) to 8.01 (PORS)

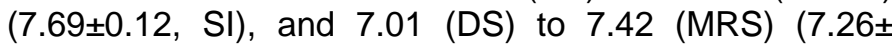
0.094 , SII). DO range from 5.1 to $5.9 \mathrm{mg} / \mathrm{l}(5.47 \pm 0.17$ $\mathrm{mg} / \mathrm{l}, \mathrm{SI})$ and $5.0 \mathrm{mg} / \mathrm{l}$ to $6.15 \mathrm{mg} / \mathrm{l}(5.56 \pm 0.27 \mathrm{mg} / \mathrm{l}, \mathrm{SIl})$. Both the highest $(6.15 \mathrm{mg} / \mathrm{l}, \mathrm{MRS})$ and lowest $(5.0 \mathrm{mg} / \mathrm{l}$, DS) were recorded in open zone.

The transparency depth varied from 32 (MRS) to $67 \mathrm{~cm}$ (PORS) $(50.25 \pm 8.46 \mathrm{~cm}, \mathrm{SI})$ and from 42 (MRS) to 97 $\mathrm{cm}$ (PORS) $(72 \pm 12.77 \mathrm{~cm}$, SII). TDSs were between 67.1 to $98.4 \mathrm{ppm}(81.8 \pm 6.94 \mathrm{ppm}, \mathrm{SI})$; and between 67.1 to $137.2 \mathrm{ppm}(102.26 \pm 15.11 \mathrm{ppm}, \mathrm{SII})$. The maximum value of TDSs (137.2 ppm) was recorded in MRS (open zone) and the minimum was $(67.1 \mathrm{ppm})$ in PORS in both sites (Table 1). $\mathrm{NO}_{3}-\mathrm{N}$ concentration extended from 0.21 (POR) to $1.85 \mathrm{mg} / \mathrm{l})(\mathrm{MR})(0.71 \pm 0.34 \mathrm{mg} / \mathrm{l}, \mathrm{SI})$, and 0.1 (DS) to $2 \mathrm{mg} / \mathrm{l}$ (MRS) $(0.758 \pm 0.43 \mathrm{mg} / \mathrm{l}$, SII). Both the highest $(2 \mathrm{mg} / \mathrm{l})$ and the lowest $(0.1 \mathrm{mg} / \mathrm{l})$ were recorded in open zone. Concentration of $\mathrm{PO}_{4}-\mathrm{P}$ ranged from 0.12 to $0.83 \mathrm{mg} / \mathrm{l}(0.388 \mathrm{mg} / \pm 0.26, \mathrm{SI})$ and 0.08 to $0.45 \mathrm{mg} / \mathrm{l}$ 


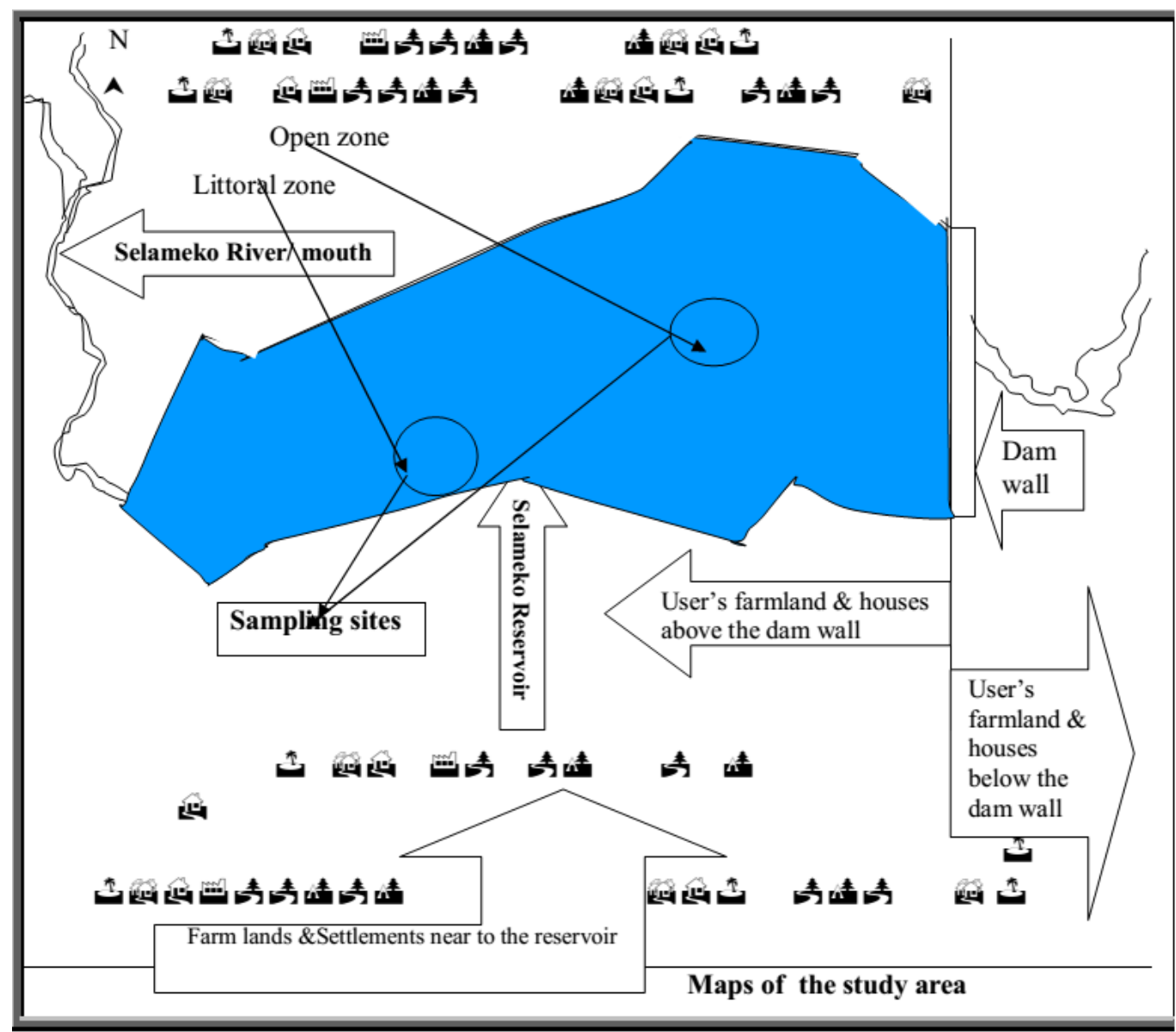

Figure 1. Map of Selameko man-made reservoir and their surrounding activities.

$(0.253 \pm 0.075 \mathrm{mg} / \mathrm{l}, \mathrm{SII})$. From the two sites, the highest was recorded in MRS $(0.83 \mathrm{mg} / \mathrm{l})$, and the lowest was recorded in PORS $(0.08 \mathrm{mg} / \mathrm{l})$. The $\mathrm{SiO}_{2}$ concentration varied from 0.66 to $22.5 \mathrm{mg} / \mathrm{l}(8.05 \pm 4.98 \mathrm{mg} / \mathrm{l}, \mathrm{SI})$ and 0.09 to $22.5 \mathrm{mg} / \mathrm{l}(8.68 \pm 5.08 \mathrm{mg} / \mathrm{l}, \mathrm{SII})$. In both sites, the maximum and the minimum values were recorded in the same season (MRS) (Table 1).

The ANOVA result showed that there were highly significant difference in temperature, $\mathrm{pH}, \mathrm{DO}, \mathrm{WTD}$, TDSs, $\mathrm{NO}_{3}-\mathrm{N}, \mathrm{PO}_{4}-\mathrm{P}$ and $\mathrm{SiO}_{2}$ among seasons and between sites (Table 1). The Tukey test also showed similar scenario. Additionally, the interactions of site and season with physicochemical parameters were significant, except pH (Table 2).

\section{DISCUSSION}

\section{Physicochemical parameters}

\section{Water temperature}

The recorded low temperature during the PORS $\left(18.7^{\circ} \mathrm{C}\right)$ was probably due to the presence of cloud that reduced sun radiation (Onyema, 2007), the accumulation of runoff in the reservoir from the streams and from watershed (Oso and Fagbuaro, 2008) and the presence of high humidity and wind in the surrounding (Atobatele and Ugwumba, 2008). The higher temperature recorded in DS $\left(24.2^{\circ} \mathrm{C}\right)$ and PRS $\left(24.1^{\circ} \mathrm{C}\right)$ was due to clear atmosphere (the absence of rain), greater solar radiation, and low water level (Moundiotiya et al.,, 2004). Therefore, the resulted temperature $\left(18.7\right.$ to $24.2^{\circ} \mathrm{C}$ ) is not exactly similar to the suggested temperature ranges of by Karai et al. (2008) (22 to $31^{\circ} \mathrm{C}$ ) for the growth of fish but in tolerable limit.

\section{Water depth}

The water depth of open zone was ranged from 10.5 Ugwumba, 2008). The higher temperature recorded in DS $\left(24.2^{\circ} \mathrm{C}\right)$ and PRS $\left(24.1^{\circ} \mathrm{C}\right)$ was due to clear atmosphere (the absence of rain), greater solar radiation, and low water level (Moundiotiya et al., 2004). Therefore, the resulted temperature $\left(18.7\right.$ to $24.2^{\circ} \mathrm{C}$ ) is not exactly similar to the suggested temperature ranges of by Karai et al. (2008) (22 to $\left.31^{\circ} \mathrm{C}\right)$ for the growth of fish but in 
Table 1. Physico-chemical parameters of Selameko Reservoir from 2009 to 2010 respect to seasons and locations. And the mean differences of (Tukey Test) Physico-chemical parameters. Means of the two columns of a particular parameter followed by the same letter (s) are not significantly different from each other $(p<0.05$, Tukey HSD) (Average $\pm S D$ ). Abbreviations used: $A v e r a g e=A v, S D=s t a n d a r d$ deviation, WTD= water transparency depth.

\begin{tabular}{|c|c|c|c|c|c|c|c|c|c|c|}
\hline \multirow{3}{*}{ Variable } & \multicolumn{5}{|c|}{ SI } & \multicolumn{5}{|c|}{ SII } \\
\hline & \multicolumn{5}{|c|}{ Seasons } & \multicolumn{5}{|c|}{ Seasons } \\
\hline & MRS & PORS & DS & PRS & $A v \pm S D$ & MRS & PORS & DS & PRS & $A v \pm S D$ \\
\hline $\mathrm{T}^{\circ} \mathrm{C}$ & $20.0^{d}$ & $18.7^{e}$ & $24.2^{a}$ & $23.1^{b}$ & $21.5 \pm 1.28$ & $19.7^{d}$ & $20.8^{c}$ & $24.2^{a}$ & $24.1^{a}$ & $22.2 \pm 1.16$ \\
\hline $\mathrm{pH}$ & $7.72^{\mathrm{ab}}$ & $8.01^{a}$ & $7.42^{b c}$ & $7.59^{b}$ & $7.69 \pm 0.12$ & $7.42^{b c}$ & $7.39^{b c}$ & $7.01^{d}$ & $7.22^{\mathrm{cd}}$ & $7.26 \pm 0.094$ \\
\hline $\mathrm{DO}(\mathrm{mg} / \mathrm{l})$ & $5.59^{b c}$ & $5.9^{\mathrm{ab}}$ & $5.1^{d}$ & $5.3^{\mathrm{cd}}$ & $5.47 \pm 0.17$ & $6.15^{\mathrm{a}}$ & $5.9^{\mathrm{ab}}$ & $5.0^{d}$ & $5.2^{\mathrm{cd}}$ & $5.56 \pm 0.27$ \\
\hline WTD $(\mathrm{cm})$ & $32^{f}$ & $67^{c}$ & $62^{\mathrm{cd}}$ & $40^{e}$ & $50.25 \pm 8.46$ & $42^{e}$ & $97^{\mathrm{a}}$ & $89^{b}$ & $60^{d}$ & $72 \pm 12.72$ \\
\hline TDSs (ppm) & $98.4^{c}$ & $67.1^{f}$ & $74.3^{\mathrm{e}}$ & $87.4^{d}$ & $81.8 \pm 6.94$ & $137.2^{a}$ & $67.1^{f}$ & $90.43^{d}$ & $114.3^{b}$ & $102.26 \pm 15.11$ \\
\hline $\mathrm{NO}_{3}-\mathrm{N}(\mathrm{mg} / \mathrm{l})$ & $1.85^{\mathrm{b}}$ & $0.21^{\mathrm{ef}}$ & $0.25^{\mathrm{e}}$ & $0.53^{d}$ & $0.71 \pm 0.34$ & $2.0^{\mathrm{a}}$ & $0.22^{\mathrm{e}}$ & $0.10^{f}$ & $0.71^{a}$ & $0.758 \pm 0.43$ \\
\hline $\mathrm{PO}_{4}-\mathrm{P}(\mathrm{mg} / \mathrm{l})$ & $0.83^{a}$ & $0.12^{\mathrm{cd}}$ & $0.44^{\mathrm{b}}$ & $0.16^{\mathrm{cd}}$ & $0.388 \pm 0.26$ & $0.45^{\mathrm{b}}$ & $0.24^{c}$ & $0.24^{c}$ & $0.08^{d}$ & $0.253 \pm 0.075$ \\
\hline $\mathrm{SiO}_{2}(\mathrm{mg} / \mathrm{l})$ & $22.5^{\mathrm{a}}$ & $6.81^{c}$ & $2.24^{d}$ & $0.66^{\mathrm{e}}$ & $8.05 \pm 4.98$ & $22.5^{\mathrm{a}}$ & $10.06^{b}$ & $2.08^{d}$ & $0.09^{f}$ & $8.68 \pm 5.08$ \\
\hline Chl-a $(\mu \mathrm{g} / \mathrm{l})$ & $39.29^{a}$ & $11.02^{\mathrm{e}}$ & $21.33^{c}$ & $17.88^{\mathrm{cd}}$ & $22.38 \pm 6.03$ & $31.23^{b}$ & $23.03^{c}$ & $15.65^{\text {de }}$ & $12.43^{\mathrm{e}}$ & $20.58 \pm 4.18$ \\
\hline
\end{tabular}

Table 2. Effects (effect test) of Sites and Seasons on the physicochemical parameters.

\begin{tabular}{|c|c|c|c|c|c|}
\hline Limnological parameter & Factors & Degree of freedom (df) & Sum of square & F-ratio & Prob. $>\mathrm{F}$ \\
\hline \multirow{3}{*}{ Temperature } & Site & 1 & 1.96 & 52.27 & $<0001$ \\
\hline & Season & 3 & 67.98 & 604.27 & $<.0001$ \\
\hline & Site *Season & 3 & 3.94 & 31.47 & $<.0001$ \\
\hline \multirow{3}{*}{$\mathrm{pH}$} & Site & 1 & 0.72 & 91.17 & $<.0001$ \\
\hline & Season & 3 & 0.53 & 22.23 & 0.0003 \\
\hline & Site *Season & 3 & 0.06 & 2.39 & 0.1440 \\
\hline \multirow{3}{*}{ Dissolved Oxygen } & Site & 1 & 0.03 & 2.55 & 0.1487 \\
\hline & Season & 3 & 2.23 & 55.52 & $<.0001$ \\
\hline & Site *Season & 3 & 0.31 & 7.40 & 0.0108 \\
\hline \multirow{3}{*}{ Transparency } & Site & 1 & 1892.3 & 630.75 & $<.0001$ \\
\hline & Season & 3 & 5392.81 & 599.19 & $<.0001$ \\
\hline & Site *Season & 3 & 236.75 & 26.31 & 0.0002 \\
\hline \multirow{3}{*}{ Conductivity } & Site & 1 & 76.56 & 136.72 & $<.0001$ \\
\hline & Season & 3 & 1591.07 & 947.06 & $<.0001$ \\
\hline & Site *Season & 3 & 363.57 & 216.41 & $<.0001$ \\
\hline \multirow{3}{*}{ Total Dissolved Substance } & Site & 1 & 1674.04 & 2470.90 & $<.0001$ \\
\hline & Season & 3 & 5827.21 & 2867.02 & $<.0001$ \\
\hline & Site *Season & 3 & 815.19 & 401.08 & $<.0001$ \\
\hline \multirow{3}{*}{$\mathrm{NO}_{3}-\mathrm{N}$} & Site & 1 & 0.01 & 10.31 & 0.0124 \\
\hline & Season & 3 & 8.05 & 3067.91 & $<.0001$ \\
\hline & Site *Season & 3 & 0.07 & 26.09 & 0.0002 \\
\hline \multirow{3}{*}{$\mathrm{PO}_{4}-\mathrm{P}$} & Site & 1 & 0.07 & 47.80 & 0.0001 \\
\hline & Season & 3 & 0.65 & 141.99 & $<.0001$ \\
\hline & Site *Season & 3 & 0.13 & 28.92 & 0.0001 \\
\hline \multirow{3}{*}{$\mathrm{SiO}_{4}$} & Site & 1 & 1.58 & 146.67 & $<.0001$ \\
\hline & Season & 3 & 1209.20 & 37385.96 & $<.0001$ \\
\hline & Site *Season & 3 & 9.33 & 288.57 & $<.0001$ \\
\hline
\end{tabular}


tolerable limit.

\section{Water depth}

The water depth of open zone was ranged from 10.5 (PRS) to $13.04 \mathrm{~m}$ (MRS). The highest reservoir water depth $(13.04 \mathrm{~m})$ was due to the high rainfall and the high surface water inflow from upstream surrounding area (river) (Meesukko et al.,, 2007; Asriningtyas et al.,, 2005); and the lowest depth was due to the presences of high evaporation, releasing of water for irrigation and dam crack.

\section{pH}

$\mathrm{pH}$ of the reservoir extended from 7.01 (SII) to $8.01(\mathrm{SI})$. The highest $\mathrm{pH}$ (8.01) was due to having much increased photosynthesis activity by phytoplanktons than the respiratory activity (Atobatele and Ugwumba, 2008; Meesukko et al., 2007) and presence of high turbulence. Low $\mathrm{pH}$ (7.01) was recorded due to reduced photosynthetic activity (Bellingham, 2004; Rafique et al., 2002); the absence of rain (Atobatele and Ugwumba,, 2008) and the decomposition of organic matter by microbial activity which was enhanced by high temperature, casing excessive production of $\mathrm{CO}_{2}$ and reduced $\mathrm{pH}$ (Moundiotiya et al., 2004). The recorded $\mathrm{Ph}$ value is good for aquatic life including fish and falls (Oso and Fagbuaro, 2008) within the EPA Redbook recommended range for fresh water (6.5 to 9.0) (Schmitz, 1996) and recommended by others (Chapman, 1996; Goldman and Horne, 1983).

\section{Dissolved oxygen}

DO ranged from $5.0(\mathrm{SI})-6.15 \mathrm{mg} / \mathrm{l}(\mathrm{SII})$. The large concentration of DO $(6.15 \mathrm{mg} / \mathrm{l})$ during MRS was probably due to the presence of low temperature that increases DO (Schmitz,, 1996; Goldman and Horne,, 1983); released from the atmosphere (Dirican et al.,, 2009; Schmitz, 1996), as a byproducts of photosynthesis from phytoplankton blooming (Wetzel and Likens,, 1991) and due to runoff (high rainfalls). The lowest $D O$ value in DS $(5.0 \mathrm{mg} / \mathrm{l})$ was due to decreased photosynthetic activity (Rafique et al.,, 2002), presence of high rates of decomposition of organic matter using relatively high temperature (Ayoola and Kuton, 2009) and presence of phytoplankton blooming (Ayoola and Kuton, 2009). The recorded DO amount satisfied the minimum recommended standard ( $>5 \mathrm{ppm}$ ) set by EPA Redbook and others (USEPA, 2008; Yajurvedi, 2008) and good for fishing.

\section{Water transparency depth}

It varied from $32 \mathrm{~cm}$ (MRS, SI) to $97 \mathrm{~cm}$ (PORS, SII). The highest transparency depth was due to the absence of relatively no suspended materials (Garg et al., 2010) and presence of small number of phytoplankton density; and the lowest was due to the presences of high surface water inflow (flooding) that assisted by rainfall that contained suspended matter. These suspended cause to increased water turbidity and reduced transparency depth in the MRS (Meesukko et al., 2007; Rafique et al., 2002), again heavy rainfall leading to an increase in phytoplankton abundance and decay of organic matter in suspension as well as released heavy sand and silt into the water (Atobatele and Ugwumba, 2008; Mustapha and Omotosho, 2005). Based on the obtained result, the reservoir water is eutrophic (Horne and Goldman, 1994) and good fishing activity.

\section{Total dissolved substances}

The TDSs of the reservoir was varied 67.1 (in PORS, SI, SII) to $137.2 \mathrm{ppm}$ (in MRS, SII). The highest value of TDSs was due to the presence large quantity of solid matters that carried by flooding and erosion caused by heavy rain (Meesukko et al., 2007; Onyema, 2007; Moundiotiya et al., 2004). The minimum TDSs were due to the absence of flood that brought allochthonous materials. This registered value is very conducive for the growth of aquatic organisms including fish (Mohamed et al., 2009; Karai et al., 2008).

\section{$\mathrm{NO}_{3}-\mathrm{N}$}

The concentration of $\mathrm{NO}_{3}-\mathrm{N}$ ranged from 0.1 (SII, DS) to $2 \mathrm{mg} / \mathrm{l}$ (SII, MRS). The highest concentration of $\mathrm{NO}_{3}-\mathrm{N}$ during in MRS was caused by the surface water inflow/flood carried high amounts of nutrients from the surrounding agricultural areas into the reservoir (Meesukko et al., 2007; Mustapha and Omotosho, 2005) and the leachates of municipal wastes from waste disposal sites and sanitary landfills (Bennett, 1998; Chapman,1996). The lowest value during DS was due to usages of algal species that fevered by high temperature (Szilagyi et al., 1988). Generally, this range of $\mathrm{NO}_{3}-\mathrm{N}(0.1$ to $2.0 \mathrm{mg} / \mathrm{l}$ ) is tolerable for fish growth and satisfy surface water quality standards $(<5 \mathrm{mg} / \mathrm{l})$ (PCD, 1997 in Chattopadhyay and Banerjee, 2007) and fulfill the minimum level of nitrate in lake to be productive (Yajurvedi, 2008).

\section{$\mathrm{PO}_{4}-\mathrm{P}$}

The amount of $\mathrm{PO}_{4}-\mathrm{P}$ was between 0.08 and $0.83 \mathrm{mg} / \mathrm{l}$. The maximum value at MRS was partly due to nutrient run-off from surrounding agricultural areas (Granit and Lindstrom, 2009; Mustapha, 2008; Oso and Fagbuaro, 2008; Chattopadhyay and Banerjee, 2007) and partly due 
to the entrances of municipal wastes, washing and bathing with phosphate based detergents and soaps (Davies et al., 2009) as well as washing of cow dung's into the reservoir (Mustapha, 2008; Schmitz, 1996). The lowest amount at PRS was due to usages of algal species (Stanley et al., 2003). The obtained concentration of $\mathrm{PO}_{4}-\mathrm{P}$ is greater than as compared to other standards (0.005 to $0.020 \mathrm{mg} / \mathrm{l} \mathrm{PO}-\mathrm{P}$ ) (Chapman, 1996) and (0.01 to $0.03 \mathrm{ppm}$ phosphorus) (Yajurveddi, 2008; Schmitz, 1996), and an indication of the presences of pollution, and therefore, bad for fishing.

\section{Silicate}

$\mathrm{SiO}_{2}$ concentration was between 0.09 (SII, DS) to 22.5 $\mathrm{mg} / \mathrm{l}$ (SI and II, MRS). The high concentration in MRS was due the effects of runoff from the watershed (Little, 2004) and the presence of high rate of rock and soil weathering in the water body (Meesukko et al., 2007; Little, 2004; Chapman, 1996); and the lowest record at PRS was due to usages of algal species (Nirmal-Kumar et al., 2009; Stanley et al., 2003). This registered silicate concentration was normal and satisfied freshwater ranges from 1 to $30 \mathrm{mg} / \mathrm{l}$ (Wetzel, 2001 in Meesukko et al., 2007; Chapman, 1996). Therefore, it is good for growth of both aquatic organisms.

\section{Conclusions}

Based on the present observation, most of the physicochemical parameters of reservoir were conducive for growth of aquatic organisms. However, high concentration of $\mathrm{PO}_{4}-\mathrm{P}$, low temperature $\left(<24.2^{\circ} \mathrm{C}\right)$, and presence of high altitude (2513 $\mathrm{m}$ above sea level) were observed which are not suitable for fishing. Based on the recorded $\mathrm{NO}_{3}-\mathrm{N}$ and $\mathrm{PO}_{4}-\mathrm{P}$ concentrations, the reservoir is under strong anthropogenic pressure. If the source of anthropogenic pressure is reduced, introduction of cold temperature resistant fish can be effective in Selameko reservoir. Therefore, both basin and reservoir management are recommended to solve such acute problems for sustainably use to hit the intended objective.

\section{Conflict of Interest}

The author declares no conflict of interest.

\section{ACKNOWLEDGEMENTS}

Author sincerely thank respected Advisor, Dr. Ayalew Wondie for his guidance and consultation. My special thank also extend to Dr. Melaku Wale for his insightful comments and suggestions for improvement of this work.
Finally, I thank Tana Fisheries and Other Aquatic Life Research Center Laboratory technicians for their unreserved support until my lab work was completed, and ANRS Bureau of Labor and Social Affairs for providing internet and other facility.

\section{REFERENCES}

Abood MM, Mohammed TA, Ghazali AH, Mahmud AR, Sidek (2009). Study and assessment for sedimentation models applied to impounding reservoirs. J. Eng. Appl. Sci. 4(2):152-160.

Asriningtyas V, Meesukko C, Gajaseni N, Voinov A (2005). Seasonal water flow trends in conjunction with phytoplankton biovolume in Phetchaburi River, Thailand. J. Sci. Resr. Chulalongkorn Univer. 30:161-178.

Atobatele OE, Ugwumba OA (2008). Seasonal variation in the physicochemistry of a small tropical reservoir (Aiba Reservoir, Iwo, Osun, Nigeria). Afr. J. Biotechnol. 7(12):1962-1971.

Ayalew W, Seyoum M, Vijverberg J, Eshetie D (2007). Seasonal variation in primary production of a large high altitude lakes (Lake Tana, Ethiopia): Effects of nutrient availability and water transparency. C. Springer science Business media B.V. P 197.

Ayoola SO, Kuton MP (2009). Seasonal variation in fish abundance and physicochemical parameters of Lagos Lagoon, Nigeria. Afr. J. Environ. Sci. Technol. 3(5):149-156.

Bennett BL (1998). Land Use Influences on Benthic Invertebrate Assemblages in Southern Appalachian agricultural streams. Virginia Polytechnic Institute and State University Blacksburg, Virginia pp. 3845.

Bellingham K (2004). Physicochemical Parameters of Natural Waters. Stevens Water Monitoring Systems, Inc.1 -800-452-5272. Retrieved on 25/4/2010, from http://www.stevenswater.com/articles/waterparameters.aspx

Bhattarai KR, Shrestha BB, Lekhak HD (2008). Water quality of Sundarijal Reservoir and its feeding streams in Kathmandu. Bhattarai, Sainik Awasiyaa Mahavidyalaya, Bhaktapur, Nepal. Sci. World 6(6):99-105

Chapman D (1996). Water Quality Assessments - A Guide to Use of Biota, Sediments and Water in Environmental Monitoring. ( $2^{\text {nd }}$ edn.). ISBN 0419215905 (HB) 0419216006 (PB) Publ. E \& FN Spon, an imprint of Chapman \& Hall. ISBN 0419215905 (HB) 041921600 6 (PB). Great Britain at the University Press, Cambridge.

Chattopadhyay C, Banerjee TC (2007). Temporal changes in environmental characteristics and diversity of net phytoplankton in a Freshwater Lake. Turkish J. Bot. 31:287-296.

Cowie G (2002). Reservoirs in Georgia: Meeting Water Supply Needs While Minimizing Impacts. River Basin Science and Policy Center Institute of Ecology, Building University of Georgia, Athens pp.1-34.

Davies OA, Abowei JFN, Otene BB (2009). Seasonal abundance and distribution of plankton of Minichinda stream, Niger Delta, Nigeria. Am. J. Sc. Res. 2(2):20-30.

Dirican S, Musual H, Cliek S (2009). Some physico-chemical characteristics and Rotifers of Camligoze Dam Lake Susehri, Sivas, Turkey. J. Anim. Vet. Adv. 8(4):715-719.

FAO (2010). Geography, Climate and Population. Water reports № 29. Retrieved on 22/1/2010, from http://www.fao.org/nr/water/aquastat/countries/eritrea/index.stm

Garg RK, Rao RJ, Uchchariya D, Shukla G, Saksena R (2010). Seasonal variations in water quality and major threats to Ramsagar Reservoir, India. Afr. J. Environ. Sci. Technol. 4(2):061-076.

Goldman CR, Horne AJ (1983). Limnology. McGraw-Hill Inc., New York, USA.

Granit J, Lindstrom A (2009). The Role of Large Scale Artificial Water Storage in the Water- Food-Energy Development. (SIWI Reference: 17-122). Stockholm International Water Institute, SIWI. Drottninggatan 33, SE-111 51, Stockholm, Sweden. pp. 9-33.

Henry R, Carmo DCF, Bicudo DC (2004). Trophic Status of a Brazilian Urban Reservoir and Prognosis about the Recovery of Water Quality Acta. Limnol. Bras.16(3):251-256. 
Holdren C, Jones W, Taggart J (2001). Managing Lakes and Reservoir. National American Lake Management Society and Terrene Inst., in coop. with Off. Water Assess. Watershed Prot. Div. U.S. Environ. Prot. Agency, Madison, WI.

Horne AJ, Goldman CR (1994). Understanding Lake Ecology. ( $2^{\text {nd }}$ ed.). McGraw-Hill. Co., New York, New York, USA.

Jansky L, Nakayama M, Uitto JI (2002). Lakes and Reservoirs as International Water Systems. United Nations University (UNU).ISBN92-808-8003-9. Omega Communications, Inc., Tokyo, Japan pp. 30-45.

Karai AL, Sahato GA, Lashari KH, Arbani SN (2008). Biodiversity in Relation to Physicochemical Properties of Keenjhar Lake, Thatta District, Sindh, Pakistan. Turkish J. Fisher. Aquat. Sci. 8:259-268.

Lee Y, Yoon T, Shah F (2009). Economics of Integrated Watershed and Reservoir Management. AAEA and ACCl Joint Annual Meeting, Milwaukee, Wisconsin. pp. 20-25.

Little JCL (2004). Influences of Artificial Desertification on Limnology Processes in Lake Samsonvale (North Pine Dam) Greenland, Australia. Griffin university Australian school of Environmental Studies Faculty of Environmental Science. Greenland, Australia.

Meesukko C, Gajaseni C, Peeraponpisal Y, Voinova A (2007). Relationships between Seasonal Variation and Phytoplankton Dynamics in Kaeng Krachan Reservoir, Phetchaburi Province, Thailand. The Natural History J. Chulalongkorn Univer. 7(2):131-143.

Mohamed AS, Thirumaran G, Arumugam R, Kannan RR, Anantharaman P (2009). Studies of Phytoplankton Diversity from Agnitheertham and Kothandaramar Koil Coastal Waters, Southeast Coast of India. Aristotle University of Thessaloniki, School of Biology, Laboratory of Ichthyology, GR-54124, Thessaloniki, Greece; Ul. Politechniczna, PL-32020 Wieliczka, Poland. Biologia, Bratislava. J. Environ. Res. 59(2):119-124.

Moundiotiya C, Sisodia R, Kulshreshtha M, Bhatia AL (2004). A Case Study of the Jamwa Ramgarh Wetland with Special Reference of Physicochemical Properties of Water and its Environs. Department of Zoology, University of Rajasthan, Jaipur and Sethi Colony, Jaipur, Rajasthan, India. J. Environ. Hydrol. 12(24):1-5.

Mustapha MK (2008). Assessment of the Water Quality of Oyun Reservoir, Offa, Nigeria, Using Selected Physico-chemical Parameters. Turkish J. Fish. Aqua. Sci. 8:309-319.

Mustapha MK, Omotosho JS (2005). An Assessment the Physicochemical Properties of Moro Lake, Kwara State Nigeria. Department of Natural Sciences, University of Ilorin, Ilorin Nigeria. Afr. J. Appl. Zool. Environ. Biol. 7:73-77.

Nancy D (2009). Florida Keys National Marine Sanctuary. Water Quality: Frequently Asked Question. pp. 1-2.

Nirmal-kumar JI, George B, Kumar RN, Sajish PR, Viyol S (2009). Assessment of Spatial and Temporal Fluctuations in Water Quality of a Tropical Permanent Estuarine System- Tapi, West Coast India. pp. 269-275.

Onyema IC (2007). The phytoplankton composition, abundance and temporal variation of a polluted Estuarine Creek in Lagos, Nigeria. Department of Marine Sciences, University of Lagos, Akoka, Lagos Nigeria. Turkish J. Fish. Aquat. Sci. 7:89-96.

Oso JA, Fagbuaro O (2008). An assessment of the physicochemical properties of a Tropical Reservoir, Southwestern Nigeria. Departments of Zoology, University of AdoEkiti, Ado Ekiti Nigeria, ISSN:1871 -3381. J. Fish. Int. 3(2):42-45.

Ostojic A, Comic L, Curcic S, Topuzovic M (2005). The Gruza Reservoir: An Ecological Study. Faculty of Science Kragujevac, Serbia and Montenegro.

Palintest Ltd (1989). Photometer systems for water analysis: Wagtech international, Palintest transmittance display photometer 5000, Palintest Ltd., UK.

Rafique RM, Mahboob S, Ahmad M, Saleem S (2002). Seasonal Limnological Variations in Mangla Reservoir at Sukhian, Mirpur (Azad Kashmir). Int. J. Agric. Biol. 4(2):223-226.
SAS (2003). Statistical Analysis System. User's Guide SAS/STA-t version. ( $8^{\text {th }}$ edt.) SAS, Institute, Inc. Cary, N.C. USA.

Schmitz RJ (1996). Introduction to Water Pollution Biology. Gulf Publishing Company. Houston, London, Paris, Zurich, Tokyo.

SPSS (2007). SPSS Survival Manual: A Step by Step Guide to Data Analysis Using SPSS for Windows. ( $3^{\text {rd }}$ edn.). Version 16.0; SPSS Inc., Chicago, IL, USA.

Stanley CD, Clarke RA, McNeal BL, Macleod BW (2003). Impact of Agricultural Land Use on Nitrate Levels in Lake Manatee, Florida. Soil and Water Science Department, Florida Cooperative Extension Service, IFAS, University of Florida. pp. 1-9.

Szilagyi F, Sorulyody L, Herodek S, Istvanove V (1988). The KisBelation Reservoir System as a Means of Controlling Eutrophication of Lake Balaton, Hungary pp. 127-150.

Straskraba, M, Tundisi JG (1999). Reservoir water quality Management. guidelines of Lake Management. International Lake Environment Committee (ILEC) Shiga, Japan Vol. 9.

Tamiru A (2006). Groundwater Occurrence in Ethiopia. UNESCO. Addis Ababa Universities, Ethiopia. P 6.

USEPA (2008). Nutrient Criteria Technical Guidance Manual Wetlands. EPA Document: EPA- 822-B-08-001.

Venkatesharaju K, Ravikumar P, Somashekar RK, Prakash KL (2010). Physico-chemical and Bacteriological Investigation on the river Cauvery of Kollegal Stretch in Karnataka. J. Sci. Eng. Technol. 6(1):50-59.

Wetzel RG, Likens GE (1991). Limnological Analyses. ( $3^{\text {rd }}$ edt.). Springer (India) Private Limited. New Delhi, India.

White WR, Bettess R (1994). The Feasibility of Flushing Sediments through Reservoirs. Challenges in African Hydrology and Water Resources (Proceedings of the Harare Symposium). Hydraulics Research Ltd, Wallingford, Oxfordshire 0X10 8BA, UK. IAHS Publ. Afr. Hydrol. Water Resour. 144:577-585.

Yajurvedi KSH (2008). A study on growth co-efficient and relative condition factor of the major carp (Catla catla) in two lakes differing in water quality. Appl. Ecol. Environ. Res. 6(3):33-47. 